\title{
SISTEM INFORMASI PENJUALAN PADA TOKO AL-IDAN VARIASI MOTOR KELURAHAN KARANG BARU, KECAMATAN MATARAM Yulia Arianti' ${ }^{1}$ Maulana Ashari ${ }^{2}$
}

\author{
Program Studi Teknik Informatika \\ Sekolah Tinggi Manajemen Informatika dan Komputer (STMIK) Lombok \\ Jln. Basuki Rahmat No.105 Praya - Lombok Tengah Telp.(0370) 654310, 653109, Faxs. (0370) 653109 \\ 1yuslizamuqofa@yahoo.com, 2aarydarkmaul@gmail.com
}

\begin{abstract}
Current trends online shopping via the Internet has mushroomed in Indonesia, even very well known by the general public. The many diverse ease of shopping and various kinds of goods and services offered, making the online shop to make Indonesian society as one of the "shopping" a new addition to the shopping center. The proliferation of online shop the many business opportunities targeting teens as consumers., The advantages of online business shop apart easily in the promotion, are also highly efficient because it only requires a subscription fee for running the business.

Production or sales system settings influence the level of acceptance of the company's revenue. Therefore, companies have to actually supervise and control the activities of sales and inventory by implementing an adequate system, so that the sales target can be achieved,. Moreover how the transaction by writing to the bill of sale that takes a long time, which resulted in the customer service to be slower.

Therefore store Al-Idan variation Mataram motors require a sales and information systems Stock items that can help process data documentation and solve the problems of data loss. With the computerized system, makes the process of selling and stock goods becomes faster. During this process of recording sales data and inventory simply by collecting a memorandum - a memorandum at a time and record it in a book report. With the web site at Al-Idan be easier for consumers to buy motorcycle accessories and spare parts that do not need to come to the store.
\end{abstract}

Keywords: spare parts, information systems, sales.

\begin{abstract}
Abstrak
Tren belanja online saat ini via internet telah menjamur di Indonesia, bahkan sangat terkenal oleh masyarakat umum. Banyak beragamnya kemudahan belanja dan berbagai jenis barang dan jasa yang ditawarkan, membuat toko online menjadikan masyarakat Indonesia sebagai salah satu "belanja" tambahan baru ke pusat perbelanjaan. Perkembangan toko online banyak peluang bisnis yang menargetkan remaja sebagai konsumen. Keunggulan toko bisnis online yang mudah dijangkau dalam promosi, juga sangat efisien karena hanya memerlukan biaya langganan untuk menjalankan bisnis.

Pengaturan sistem produksi atau penjualan mempengaruhi tingkat penerimaan pendapatan perusahaan. Oleh karena itu, perusahaan harus benar-benar mengawasi dan mengendalikan kegiatan penjualan dan inventarisasi dengan menerapkan sistem yang memadai, sehingga target penjualan dapat tercapai,. Apalagi bagaimana transaksi dengan cara menulis ke tagihan penjualan yang memakan waktu lama, yang mengakibatkan customer service menjadi lebih lambat.

Oleh karena itu toko variasi Al-Idan motor Mataram memerlukan sistem penjualan dan informasi Stok barang yang dapat membantu proses dokumentasi data dan memecahkan masalah kehilangan data. Dengan sistem komputerisasi, membuat proses penjualan dan stok barang menjadi lebih cepat. Selama proses pencatatan data penjualan dan inventaris ini hanya dengan mengumpulkan nota-nota sekaligus dan mencatatnya dalam laporan buku. Dengan adanya situs web di Al-Idan ini memudahkan konsumen untuk membeli aksesoris motor dan suku cadang yang tidak perlu datang ke toko.
\end{abstract}

Kata kunci: suku cadang, sistem informasi, penjualan. 


\section{Pendahuluan}

\subsection{Latar Belakang}

Saat ini trend berbelanja online melalui media internet sudah menjamur di Indonesia, bahkan sudah sangat dikenal baik oleh khalayak ramai. Banyaknya beragam kemudahan dalam berbelanja dan bermacam jenis produk barang dan jasa yang ditawarkan, membuat masyarakat indonesia menjadikan online shop sebagai salah satu "tempat berbelanja" baru selain pusat perbelanjaan. Hal ini membuat banyak online shop berlomba-lomba menawarkan produknya dengan berbagai cara untuk menarik konsumen berbelanja.[12]

Menjamurnya online shop membuka peluang usaha yang banyak membidik remaja sebagai konsumennya. Keunggulan bisnis online shop selain mudah dalam melakukan promosi, juga sangat efisien karena hanya membutuhkan biaya berlangganan internet untuk menjalankan bisnisnya. Sistem penjualan dan stok barang merupakan bagian yang penting dalam pengoperasian suatu perusahaan, baik perusahaan manufaktur maupun perusahaan dagang.

Pembuatan atau pengaturan sistem penjualan berpengaruh pada tingkat penerimaan pendapatan perusahaan, sedangkan sistem stok barang memberikan pengaruh pada informasi penerimaan barang yang diperoleh dari supplier. Oleh karena itu perusahaan harus benar-benar mengawasi dan mengendalikan kegiatan penjualan serta stok barang dengan menerapkan sistem yang memadai, sehingga target penjualan dapat dicapai,. Selain itu cara transaksi dengan menulis ke nota penjualan membutuhkan waktu lama, yang mengakibatkan pelayanan kepada pelanggan menjadi lebih lambat.

Oleh karena itu toko Al-idan variasi motor Mataram membutuhkan suatu Sistem penjualan dan informasi Stok barang yang dapat membantu proses dokumentasi data dan mengatasi permasalahan kehilangan data. Dengan adanya sistem yang terkomputerisasi, membuat proses penjualan dan stok barang menjadi lebih cepat. Selama ini proses pencatatan data penjualan dan stok barang hanya dilakukan dengan mengumpulkan nota - nota dalam satu waktu serta mencatatnya ke dalam buku laporan. Hal tersebut melatar belakangi "Perancangan Sistem Informasi Penjualan dan Stok Barang pada toko Al-idan variasi motor Mataram".

\subsection{Rumusan Masalah}

Permasalahan-permasalahan yang ada di toko Al-idan variasi motor adalah sebagai berikut:

1. Kehilangan data penjualan dan data pembelian yang sering terjadi.

2. Pembuatan laporan dengan mengumpulkan nota-nota penjualan dan pembelian membutuhkan waktu yang lebih lama.

\subsection{Batasan Masalah}

Agar permasalahan menjadi lebih terarah, maka peneliti memberikan batasan masalah pada masalah yang akan dibahas, yaitu:

1. Membuat sistem informasi data penjualan,data pembelian dan pembuatan laporan.

2. Membuat sistem informasi penjualan dan pembelian berbasis online.

\subsection{Tujuan Penelitian} berikut:

Tujuan dari penelitian adalah sebagai

1. Menghasilkan sistem informasi berbasis web sehingga dapat menawarkan dan menjual barang secara online.

2. Untuk menghasilkan sistem informasi data barang, data transaksi dan laporan yang tersimpan di dalam database.

\subsection{Manfaat Penelitian}

Adapun mamfaat dari penelitian adalah sebagai berikut:

1. Dapat memberikan informasi lebih cepat dan tepat mengenai data traansaksi dan data barang.

2. Memberi kemudahan bagi konsumen untuk mengetahui informasi barang dan harga barang yang ada di toko Al-idan.

\section{TINJAUAN PUSTAKA}

Penelitian yang dilakukan oleh Astuti (2012) dalam papernya yang berjudul Perancangan Sistem Informasi Penjualan Obat Pada Apotik Jati Farma Arjosari, tujuan penelitian adalah untuk membuat sistem informasi penjualan yang terkomputerisasi. Dengan adanya sistem informasi penjualan obat dapat memudahkan proses pencatatan data obat dan data transaksi, kekurangan dari sistem adalah tidak adanya sistem pengolahan data obat yang masuk dan data obat yang keluar.

Penelitian yang dilakukan oleh Febianto (2012) dalam jurnal yang berjudul Analisis Dan Perancangan Sistem Informasi Penjualan Pada Toko Karunia Sintang Kalimantan Barat. Tujuan 
penelitian adalah untuk membuat sistem informasi penjualan dan stok barang. Dengan adanya sistem informasi yang terkomputerisasi dapat membantu toko Karunia mendapatkan informasi yang lebih cepat, jelas dan akurat. Kekurangan dari sistem adalah tidak memuat data supplier/pemasok.

Penelitian yang dilakukan oleh Dwi Pusbarini dan Hilma Yuliana S.F (2011) dalam jurnalnya yang berjudul Aplikasi Sistem Penjualan Spare Part Pada Essen Automobil Palembang, menghasilkan sistem informasi penjualan yang dapat meminimalisir kesalahan dalam pencatatan harga barang pada proses transaksi penjualan dan mempermudah dalam pencarian data stok barang di gudang, kekurangan dari penelitian ini adalah masih terjadinya keterlambatan dalam proses pengiriman barang.

Penelitian yang dilakukan oleh Nailun Nafar (2011) dalam skripsinya yang berjudul Sistem Informasi Penjualan Pada Toko Besi Impla Bangun Jepara, menghasilkan sistem informasi penjualan yang dapat mempercepat proses transaksi karena telah menggunakan komputer secara maksimal untuk pengolahan data dan dimuat dalam bentuk laporan yang apabila sewaktu-waktu diperlukan oleh Manager dapat di cetak secara cepat. Kekurangan dari penelitian ini adalah sistem pembayarannya masih bersipat manual yaitu pembeli harus datang ke Bank untuk melakukan pembayaran.

Penelitian yang dilakukan oleh Wibowo (2011) dalam paper yang berjudul sistem informasi persediaan keluar masuk barang pada inside distro jakarta. Dijelaskan bahwa implementasi di lapangan menghadapi kendala utama ketika di sistem informasi keluar masuk barang di bagian gudang, akan tetapi dengan adanya sistem informasi persedian barang dapat membantu dan mempercepat pengolahan data keluar masuk barang, adapun kekurangan dari penelitian ini adalah tidak adanya proses transaksi dan hanya memuat pengolahan data keluar masuk barang.

\section{METODOLOGI PENELITIAN}

\subsection{Flowmap yang sedang berjalan}

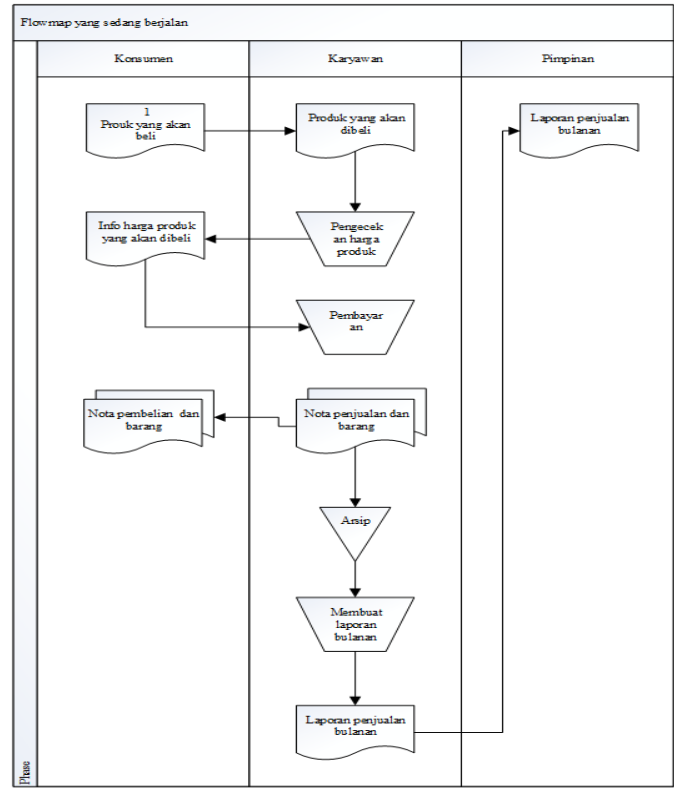

Gambar 3.1 flowmap yang sedang berjalan

\subsection{Flowmap Usulan}

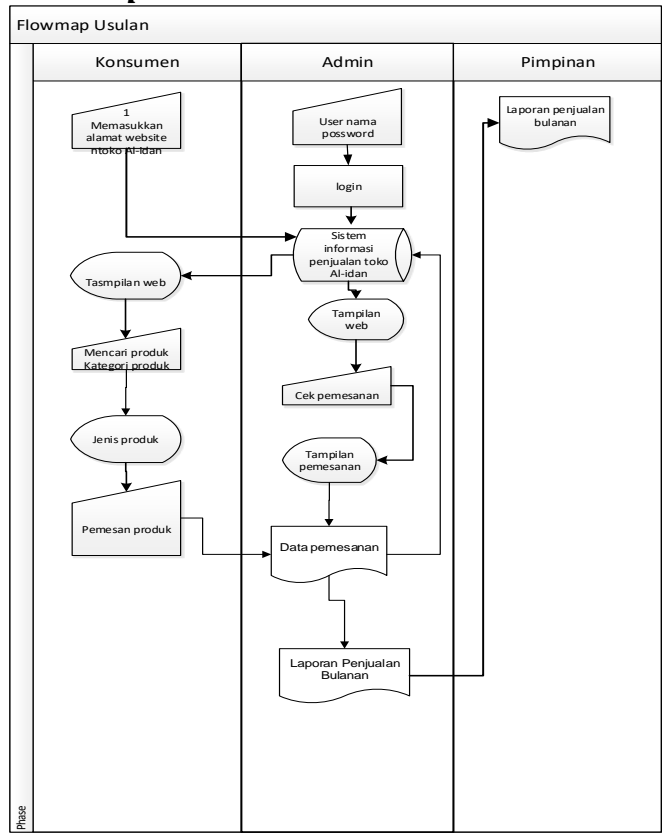

Gambar 3.2 flowmap usulan

\subsection{Diagram Konteks}

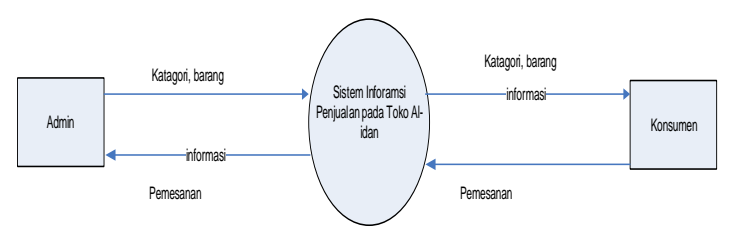

Gambar 3.3 diagram konteks 


\subsection{DFD level 1}

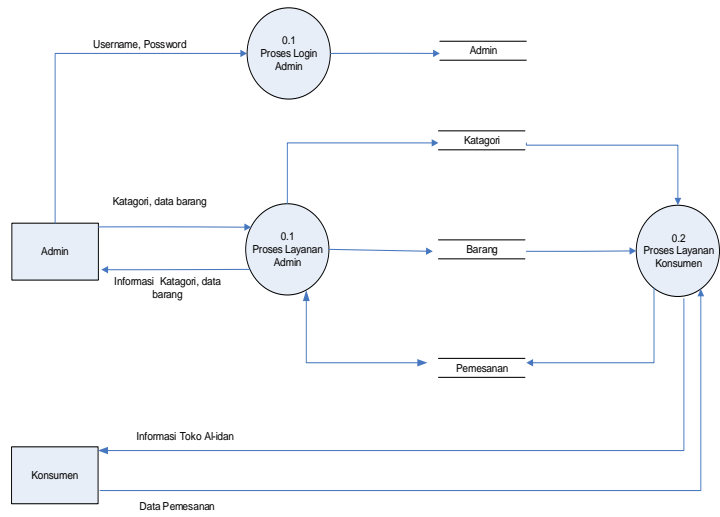

Gambar 3.4 DFD level 1

\subsection{DFD level 1 proses admin}

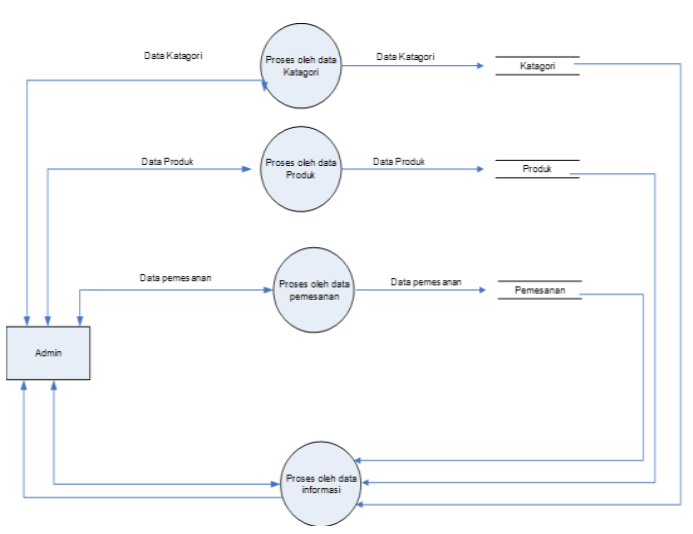

DFD level 1 proses admin

3.6 DFD level 1 Konsumen

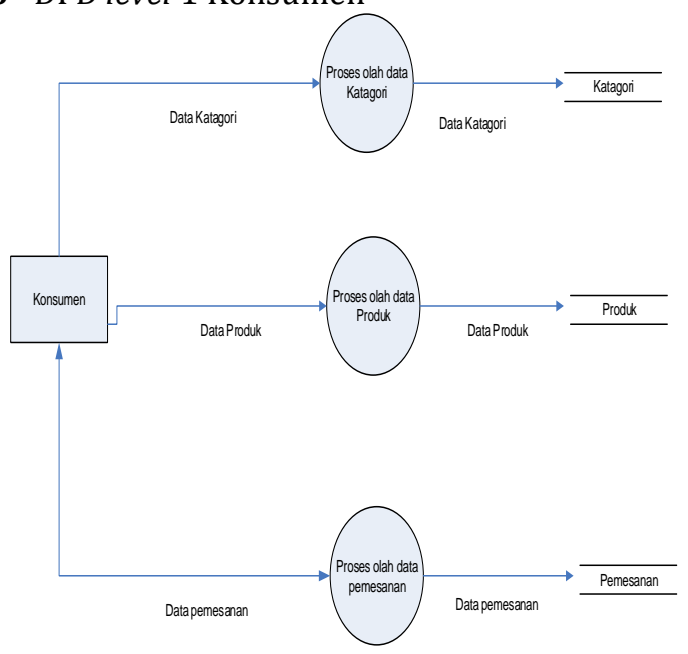

Gambar 3.6 DFD level 1 konsumen

\subsection{Relasi Antar Tabel}

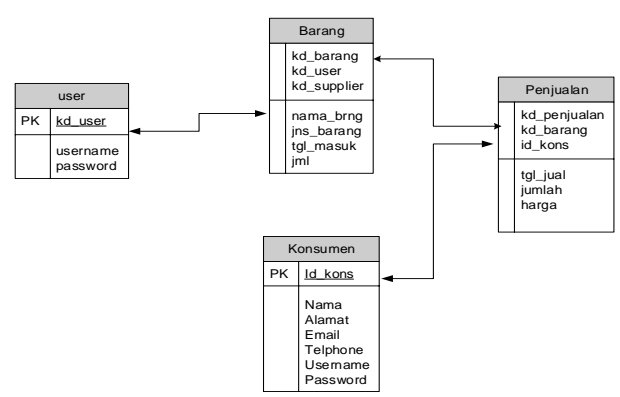

Gambar 3.7 Relasi Antar Tabel

4. HASIL DAN PEMBAHASAN

4.1 Tampilan halaman login admin

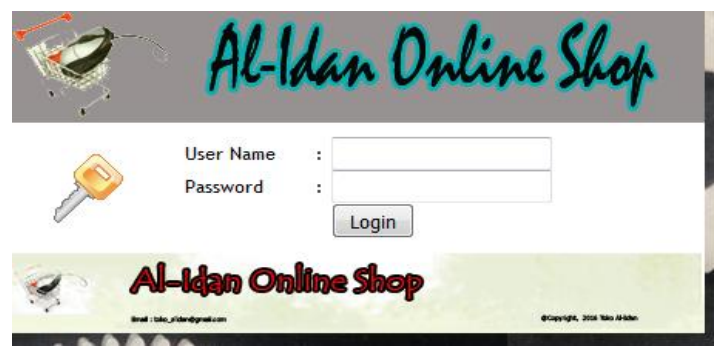

Gambar 4.1 halaman login admin

4.2 Tampilan Menu Utama Admin

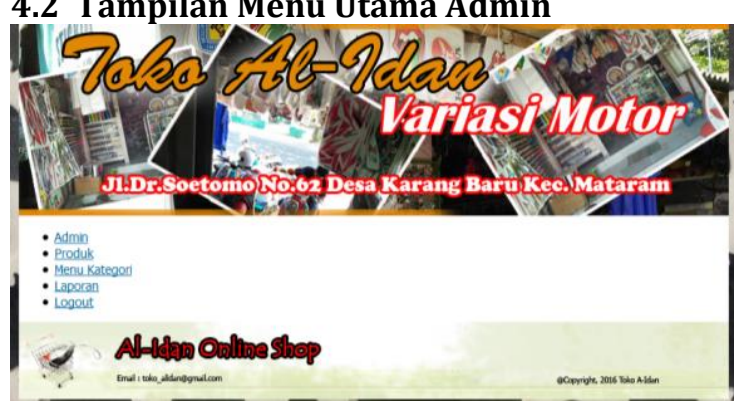

Gambar $4 . \overline{2}$ menu utama admin

4.3 Tampilan menu produk pada halaman admin

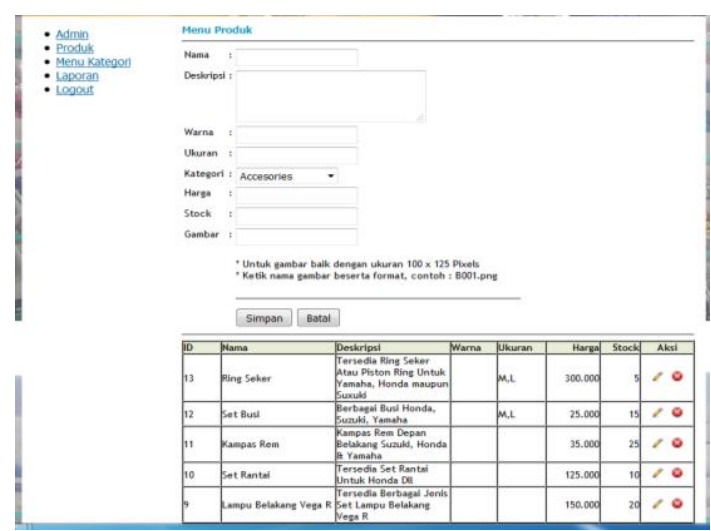

Gambar 4.3 tampilan menu produk pada halaman admin 


\subsection{Tampilan menu kategori pada halaman}

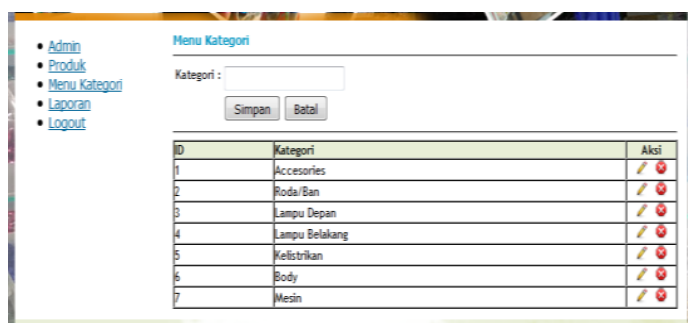

Gambar 4.4 tampilan menu kategori pada halaman admin

4.5 Tampilan menu laporan pada halaman admin

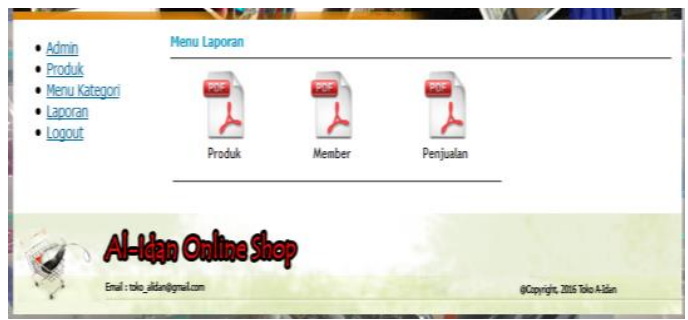

Gambar 4.4 tampilan menu laporan pada halaman admin

\subsection{Tampilan halaman utama konsumen}

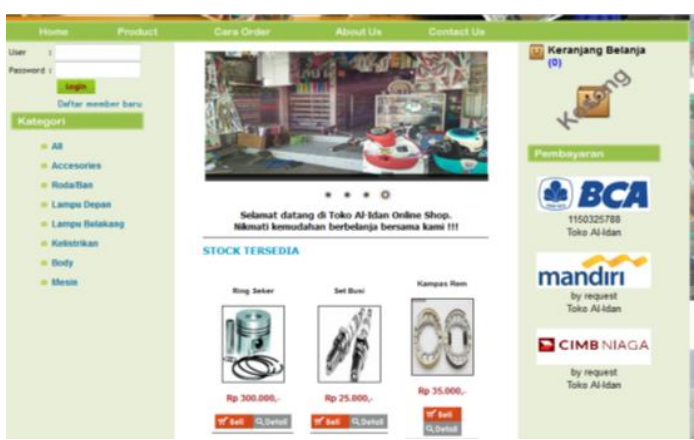

Gambar 4.6 tampilan menu utama konsumen

4.7 Tampilan form daftar member

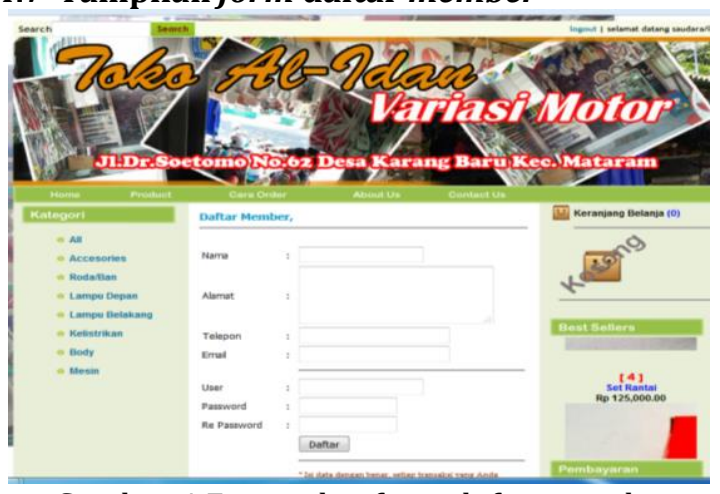

Gambar 4.7 tampilan form daftar member
4.8 Tampilan menu produk pada halaman konsumen

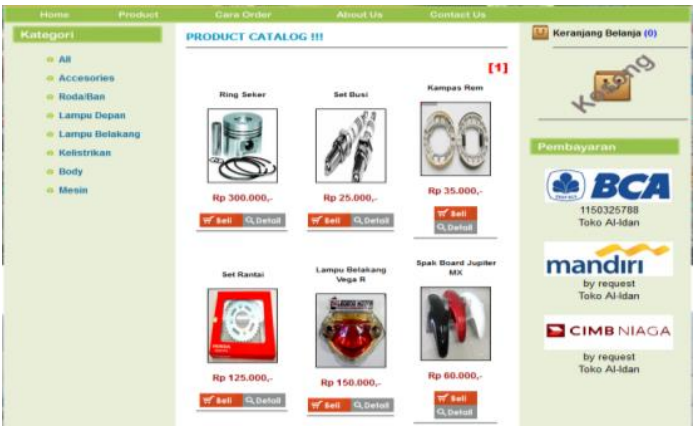

Gambar 4.8 Tampilan Menu Produk Pada Halaman Konsumen

\subsection{Tampilan nama produk dan harga produk yang telah di pesan}

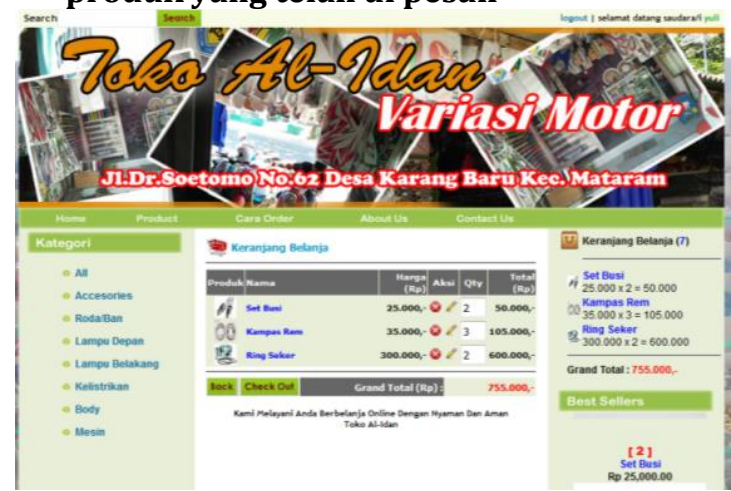

Gambar 4.9 Tampilan nama produk dan harga produk yang telah di pesan

\section{PENUTUP}

\subsection{Kesimpulan}

Kesimpulan yang dapat diambil berdasarkan bab-bab sebelumnya adalah:

1. Keberadaan situs web Toko Al-idan dapat mempermudah konsumen untuk membeli aksesoris dan spare part motor sehingga tidak perlu langsung datang ke toko.

2. Perbandingan proses transaksi secara manual dan secara online yaitu Transaksi secara manual pada jarak $10 \mathrm{~km}$ waktu yang dibutuhkan untuk datang ke toko membutuhkan waktu sekitar 40 menit, kemudian waktu yang dibutuhkan untuk memilih barang sampai proses transaksi membutuhkan waktu sekitar 10 menit, setelah itu waktu yang dibutuhkan untuk balik lagi kerumah 40 menit. Jadi waktu yang dibutuhkan untuk proses pembelian barang/transaksi secara manual adalah 90 menit atau satu jam setengah. Sedangkan transaksi melalui media online Proses transaksi melalui media online hanya membutuhkan waktu 10 menit untuk membuka sistem/situs web, memilih barang sampai dengan proses transaksi. 
3. System informasi berbasis web dapat digunakan sebagai alternatif sistem yang lama karena dengan adanya sistem informasi ini dapat memudahkan karyawan dalam pembuatan laporan karena pada saat proses transaksi online dilakukan semua data-data transaksi langsung tersimpan didalam database.

\subsection{Saran-saran}

Saran-saran yang diberikan untuk penelitian berikutnya adalah :

1. Untuk dapat mengoperasikan komputer secara maksimal dibutuhkan sumber daya manusia yang bisa menggunakan komputer, sehingga sistem yang digunakan dapat dimanfaatkan secara optimal.

2. Meningkatkan keamanan pada sistem dengan menambahkan anti virus.

\section{DAFTAR PUSTAKA}

Dari, Wulan. 2015, Penerapan Metode System Development Life Cycle Pada Pembuatan Sistem Informasi Penjualan Produk Batik Kurowo Jakarta.

Handoyo, Erry. 2011, Aplikasi pemesanan spare part motor berbasis web.

Anonim, 2016, Buku Panduan Penulisan Tugas Akhir, STMIK Lombok, Praya.

Jogiyanto. HM. 1989. Analisa Dan Desain Sistem Informasi. Andi Offset Yogyakarta.

Bahtiar, Agus, 2008. Membangun Situs Dengan PHP Untuk Orang Awam. Maxikom. Yogyakarta.

Pressman, 2002. Notasi dasar DFD.Yogyakarta
Kadir, Abdul 2009. Mudah Mempelajari Database MySQL. ANDI, Yogyakarta

Fathansyah, 2012. Basis Data. Informatika, Bandung.

Sutabri, Tata, 2012. Konsep dasar sistem informasi. Yogyakarta

Samantha, Donna Primasari. 2011, Perancangan Sistem Informasi Pada Toko Sahaaba. Diss. undip.

Muawanah, Siti, dkk, 2012. Analisis Pemanfaatan Situs Web Di Psta Lapan Mengunakan Metode Pieces.Palembang.

Aeweidya, 2011, Analisis Pengaruh Harga Barang Dan Media Promosi.

Wire Bagye. "Analisis Tingkat Kematangan Sistem Informasi Akademik Menggunakan Framework COBIT 4.1 (Studi Kasus: STMIK Lombok)." Speed-Sentra Penelitian Engineering dan Edukasi 8.1 (2016).

Ahmad Susan Pardiansyah. "Audit Tata Kelola Teknologi Informasi Program Studi Sistem Informasi Sekolah Tinggi Manajemen Informatika Dan Komputer (STMIK) Lombok Menggunakan." IJSE-Indonesian Journal on Software Engineering 1.1 (2015).

Hodia, Maelani, and Khairul Imtihan-STMIK Lombok. "Perancangan Sistem Informasi Praktek Klinik Kebidanan (PKK) Pada Prodi DIII Kebidanan Stikes Qamarul Huda." IJNSIndonesian Journal on Networking and Security 6.3 (2017).

Khairul Imtihan. "Perencanaan Strategi Sistem Informasi Pendidikan Pada Sekolah Tinggi Manajemen Informatika dan Komputer (STMIK) Lombok." Bianglala Informatika 3.2 (2015). 